\title{
51. CONSOLIDATION CHARACTERISTICS AND PERMEABILITY OF MISSISSIPPI FAN SEDIMENTS ${ }^{1}$
}

\author{
William Bryant, Texas A\&M University \\ Andreas Wetzel, Universität Tübingen \\ Elliott Taylor, Texas A\&M University \\ and
}

William Sweet, Mineral Management Service ${ }^{2}$

\begin{abstract}
Geotechnical properties of Quaternary sediments from the middle and lower regions of the Mississippi Fan show that the sediments are normally to overly consolidated to a depth of 40 to $50 \mathrm{~m}$ below the seafloor. Below that depth, the sediments become highly underconsolidated and exhibit high excess pore-water pressures. The state of underconsolidation is attributed to the rapid rates of sediment accumulation and the low permeability of smectite-rich clays.
\end{abstract}

\section{INTRODUCTION}

An extensive geotechnical sampling program was carried out during Deep Sea Drilling Project (DSDP) Leg 96 on the Mississippi Fan. Of the nine sites drilled, eight produced excellent quality cores using the advanced piston corer (APC) and the extended core barrel (XCB) at Sites $614,615,616,617,621,622,623$, and 624 (Fig. 1). The high quality of the cores was also attributed to the absence of methane and other gases. The cores taken at Site 620 were recovered by the use of rotary drilling and, therefore, were highly disturbed. Duplicate APC cores collected at Sites $615,616,617$, and 624 were dedicated exclusively for shore-based geotechnical investigations. Analyses of those geotechnical cores will be conducted by the Marine Geotechnical Consortium. The preliminary results of the onshore geotechnical analyses and the data collected on board the Glomar Challenger are reported in this chapter; further results of the shore-based geotechnical results will be reported by the Geotechnical Consortium in a later publication.

The majority of sediments cored on the Mississippi Fan were deposited during the late Wisconsin glacial (Ericson's Y zone; Ericson and Wollin, 1968). Because of the high sedimentation rates of these sediments, over $11 \mathrm{~m} / 1000 \mathrm{yr}$. for the middle fan and over $5 \mathrm{~m} / 1000 \mathrm{yr}$. for the lower fan regions (Wetzel and Kohl, this volume), all sediments were expected to be underconsolidated.

Underconsolidation is the condition where the weight of overlying sediments and the pore-water pressures at a given depth are in disequilibrium, with the overburden stress resulting in pore-water pressures in excess of hydrostatic pressure. A state of total underconsolidation

\footnotetext{
${ }^{1}$ Bouma, A. H., Coleman, J. M., Meyer, A. W., et al., Init. Repts. DSDP, 96: Washington (U.S. Govt. Printing Office).

2 Addresses: (Bryant) Department of Oceanography, Texas A\&M University, College Station, TX 77843; (Wetzel) Geologisches Institut der Universität Tübingen, Sigwartstrasse 10, D7400 Tübingen, Federal Republic of Germany; (Taylor, present address) Ocean Drilling Program, 500 University Drive West, Texas A\&M University, College Station, TX 77843; (Sweet) Mineral Management Service, P.O. Box 7944, Metairie, LA 77010.
}

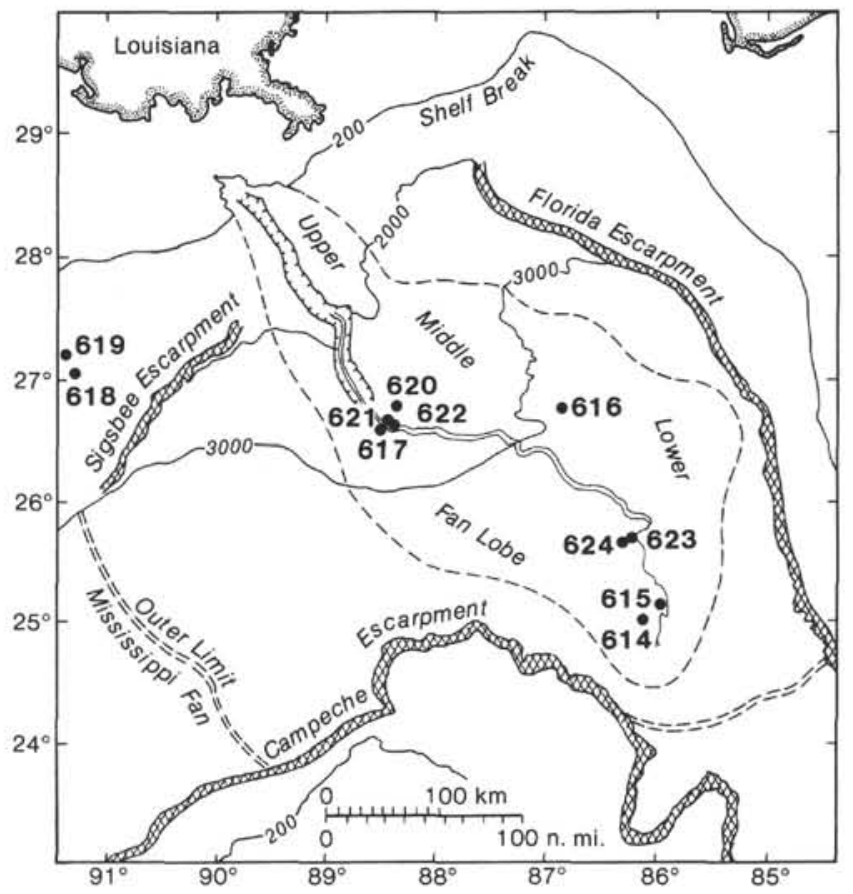

Figure 1. Location of Leg 96 sites.

exists when the pore-water pressures are equal to the total vertical effective stress plus the hydrostatic pressure (geostatic pressure). A state of normal consolidation is where the pore-water pressures are equal to the hydrostatic pressure. Overconsolidation is the state where the fabric of the sediments is capable of supporting a load far in excess of the existing overburden. Overconsolidation results from unusual bonding or the removal of pre-existing overburden by erosional processes or mass movement.

High rates of sediment accumulation and low permeabilities are the usual causes of underconsolidation. The permeabilities of the clays on the Mississippi Fan are extremely low. These clays are composed of about 70 to 
$80 \%$ smectite and have coefficients of permeabilities in the $10^{-6} \mathrm{~cm} / \mathrm{s}\left(10^{-3}\right.$ darcys) range for the near-surface sediments and $10^{-11} \mathrm{~cm} / \mathrm{s}\left(10^{-8}\right.$ darcys) for sediments at $550 \mathrm{~m}$ sub-bottom depth (Bryant, Wetzel, and Sweet, this volume; also, see below).

The primary objective of this study was to define the degree of consolidation and the pore-water pressure conditions of Mississippi Fan sediments and to investigate what such conditions may mean to the sediment column. For example, excess pore-water pressures can have a profound influence on the in situ shear strength and other geotechnical properties. The principle of effective stress states that the effective stress $(\bar{\sigma})$ is equal to the total stress $(\sigma)$ minus the pore pressure $(u)$ :

$$
\bar{\sigma}=\sigma-u \text {. }
$$

The state of effective stress correlates more closely with sediment behavior than either total stress or pore-water pressure. An increase in the effective stress should cause the sediment particles to shift into a denser packing, whereas equal and simultaneous increases in the total stress and the pore-water pressure would keep the effective stress constant and would have little or no effect on the particle packing (Lambe, 1951).

The dramatic fashion in which the shearing resistance of a sediment can be affected by excess pore-water pressure is shown by examination of the following equation:

$$
S_{\mathrm{u}}=c+\bar{\sigma} \tan \phi
$$

where $S_{\mathrm{u}}=$ undrained shear strength, $c=$ cohesion, $\bar{\sigma}$ $=$ vertical effective stress (see Eq. 1), and $\phi=$ angle of internal friction.

As the pore-water pressure increases, the value of the vertical effective stress decreases. For the condition where a state of total underconsolidation exists, the value of the effective stress is zero, in which case the shear strength is then equal only to the cohesion of the sediment. Under these conditions, the shearing resistance of the sediments remains constant with depth, and the deposits are unstable on almost any degree of slope.

Overpressured formations, which are very common in the Gulf Coast area, are generally the result of high excess pore-water conditions resulting from compaction (consolidation) disequilibrium and other conditions. In highly underconsolidated sediments, such as certain Mississippi Fan sediments, overpressured conditions can be encountered at fairly shallow depths below the seafloor.

\section{CONSOLIDATION CHARACTERISTICS INFERRED FROM SEDIMENT SHEAR STRENGTH}

The most direct and definitive way of determining the degree of consolidation for normally and underconsolidated sediment conditions is to measure the in situ porewater pressures. Only in rare cases has that been achieved at DSDP sites drilled throughout the world.

Another method to approximate the conditions of consolidation is to examine the relationship between shear strength and overburden stress. Skempton (1970) devised a method based on empirical relationships for predicting the shear strength-overburden stress ratio for normally consolidated marine sediments. This relationship is given in the following equation:

$$
S_{\mathrm{u}} / \bar{\sigma}_{\mathrm{z}}=0.11+0.0037 I_{\mathrm{p}}
$$

where $S_{\mathrm{u}}=$ shear strength, $\bar{\sigma}_{\mathrm{z}}=$ overburden stress, and $I_{\mathrm{p}}=$ plasticity index.

Figures 2, 3, and 4 show ratios of shear strength to overburden stress plotted against sub-bottom depth for sediments collected from the middle fan region at Sites $616,617,621,622$, and 620 . Figures 5 and 6 are plots of the same relationships for the lower fan sediments collected at Sites $614,615,623$, and 624. The plots include a vertical line with a value of 0.22 . This line represents the limits derived from Skempton's relationship, as expressed above, for normally consolidated sediments with plasticity indices of 0.25 . All values of the shear strengthoverburden stress ratio less than 0.22 are, therefore, assumed to be underconsolidated; those with values larger than 0.22 are considered to be either normally consolidated or overconsolidated.

\section{Consolidation Characteristics of Middle Fan Sediments}

The sediments recovered at Site 617 are levee/overbank deposits consisting of thin, fine-grained turbidite sequences (see Site 617 chapter, this volume). Figure 2 shows that the upper $60 \mathrm{~m}$ of the sediments at this site are predominantly underconsolidated, the 60 to $90 \mathrm{~m}$

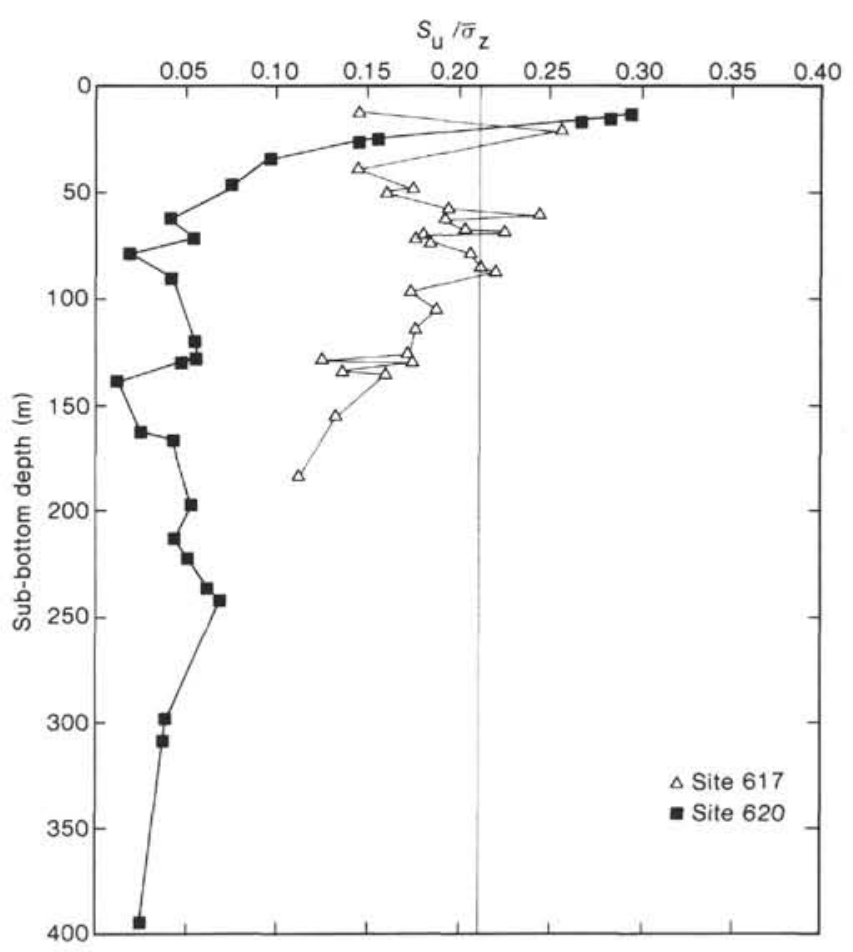

Figure 2. Undrained shear strength-effective overburden stress ratio $\left(S_{\mathrm{u}} / \bar{\sigma}_{\mathrm{z}}\right)$ for Sites 617 and 620 . Sediments with ratios less than 0.22 (to the left of the vertical line) are underconsolidated. 
sub-bottom interval is normally consolidated, and the sediments below $90 \mathrm{~m}$ are underconsolidated, with the degree of underconsolidation increasing with depth in the hole.

Site 620 is located approximately $18 \mathrm{~km}$ northeast of the channel in the overbank region (see Site 620 chapter, this volume). The clay and silty clay recovered at this site are normally consolidated in the upper $25 \mathrm{~m}$ of the section and highly underconsolidated at all depths below the $25-\mathrm{m}$ level (Fig. 2). Most sediments from Site 620 were highly disturbed as a result of rotary drilling techniques used to recover the cores. This disturbance may explain the excessively low shear strength measured at Site 620 .

Sites 621 and 622 were drilled in the midfan channel (see site chapters, this volume). Both sites contain clay and mud to a depth of approximately $135 \mathrm{~m}$ below the seafloor. Below this level the sediments become sandy, the amount of sand increasing with depth, and finally give way to loose sand and gravel at around $200 \mathrm{~m}$ subbottom depth. At both channel sites, the sediments became underconsolidated at a depth of 40 to $50 \mathrm{~m}$, with the degree of underconsolidation increasing with depth (Fig. 3).

Site 616 was drilled in the easternmost margin of the youngest fan lobe at a site described as a surface slump by Walker and Massingill (1970). The upper $90 \mathrm{~m} \mathrm{sec-}$ tion of fine-grained mud and silty clay exhibits extremely steep dipping beds (ranging up to $65^{\circ}$ ), suggesting deposition by mass movement. Below this disturbed zone, the sediments are dominantly silt-laminated muds with minor sand layers (see Site 616 chapter, this volume).

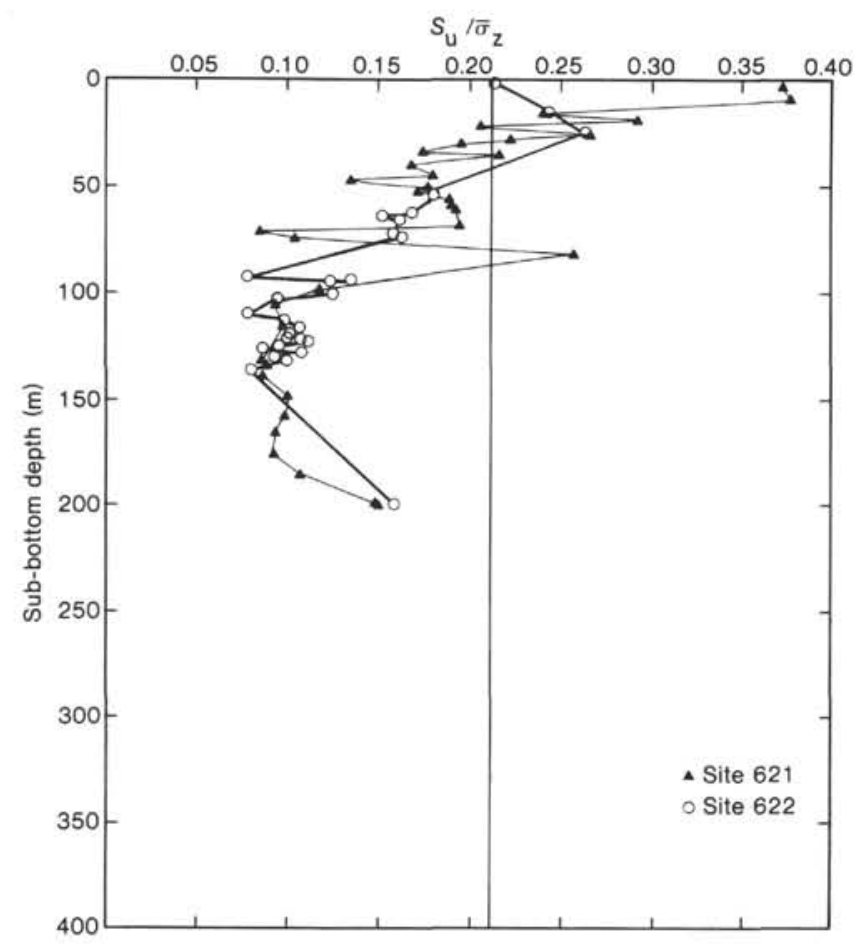

Figure 3. Undrained shear strength-effective overburden stress ratio $\left(S_{\mathrm{u}} / \bar{\sigma}_{2}\right)$ for Sites 621 and 622 . Sediments with ratios less than 0.22 (to the left of the vertical line) are underconsolidated.
The sediments at Site 616 are normally consolidated to a depth of $40 \mathrm{~m}$, slightly underconsolidated to a depth of $95 \mathrm{~m}$, and highly underconsolidated below that depth (Fig. 4). It is unusual that the large Holocene or late Pleistocene mass-movement deposit recovered from 0 to $90 \mathrm{~m}$ sub-bottom should contain normally consolidated sediments; it is also unusual that a massive slump should contain well preserved primary sediment structures. In fact, the only indication of mass movement is the appearance of inclined strata (see Site 616 chapter, this volume). However, the sediments directly below the slump exhibit evidence of being rapidly loaded (i.e., they are highly underconsolidated), which adds support to our interpretation that the uppermost sediments represent a mass-movement deposit.

\section{Consolidation Characteristics of Lower Fan Sediments}

Sites 623 and 624 were drilled adjacent to the main channel in the lower fan (see site chapters, this volume). The strength-overburden stress ratios of the sediments (terrigenous clay and mud; silty mud and silt; and silty sand and sand) at both sites indicate that the sediments are normally consolidated in the upper $40 \mathrm{~m}$ and slightly underconsolidated below that level (Fig. 5).

Sites 614 and 615 were drilled in the lower fan near the ends of the channel into its associated depositional lobe. Large amounts of sand were recovered from both sites. Sand makes up an estimated $70 \%$ of the total sediment column at Site 614 and $57 \%$ at Site 615 (see site chapters, this volume). The remaining sediments consist primarily of clay and silty clay. A 29-m-thick nannofossil ooze unit deposited during Ericson Zone $\mathrm{X}$ was pene-

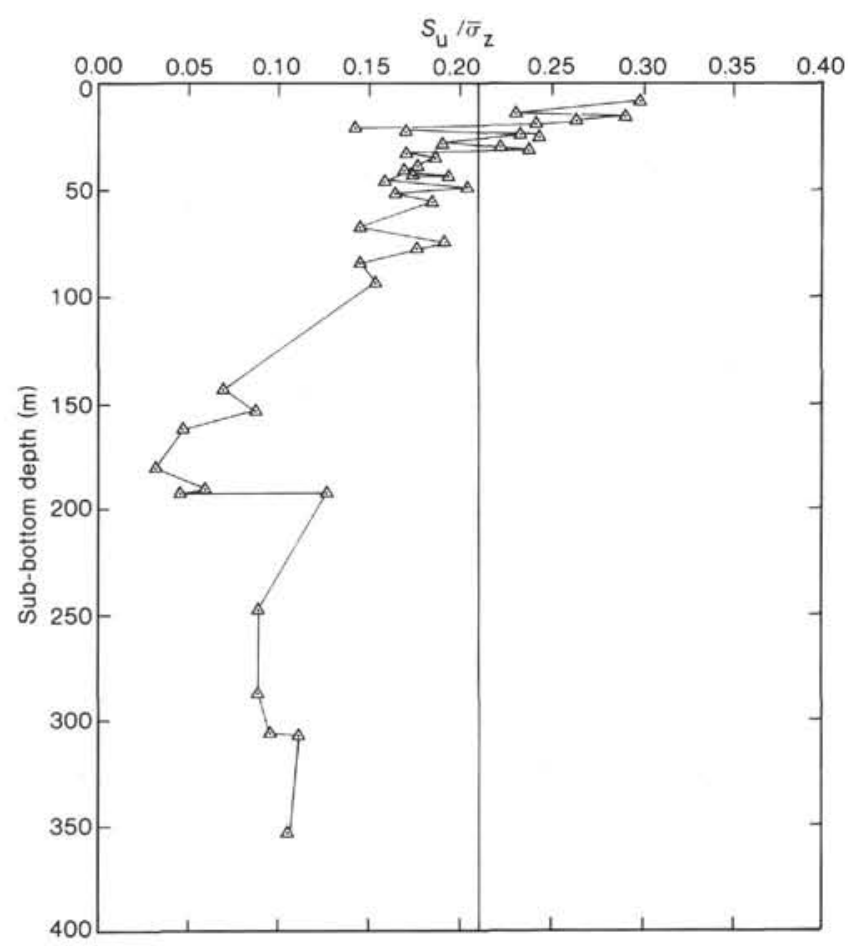

Figure 4. Undrained shear strength-effective overburden stress ratio $\left(S_{u} / \bar{\sigma}_{z}\right)$ for Site 616 . Sediments with ratios less than 0.22 (to the left of the vertical line) are underconsolidated. 


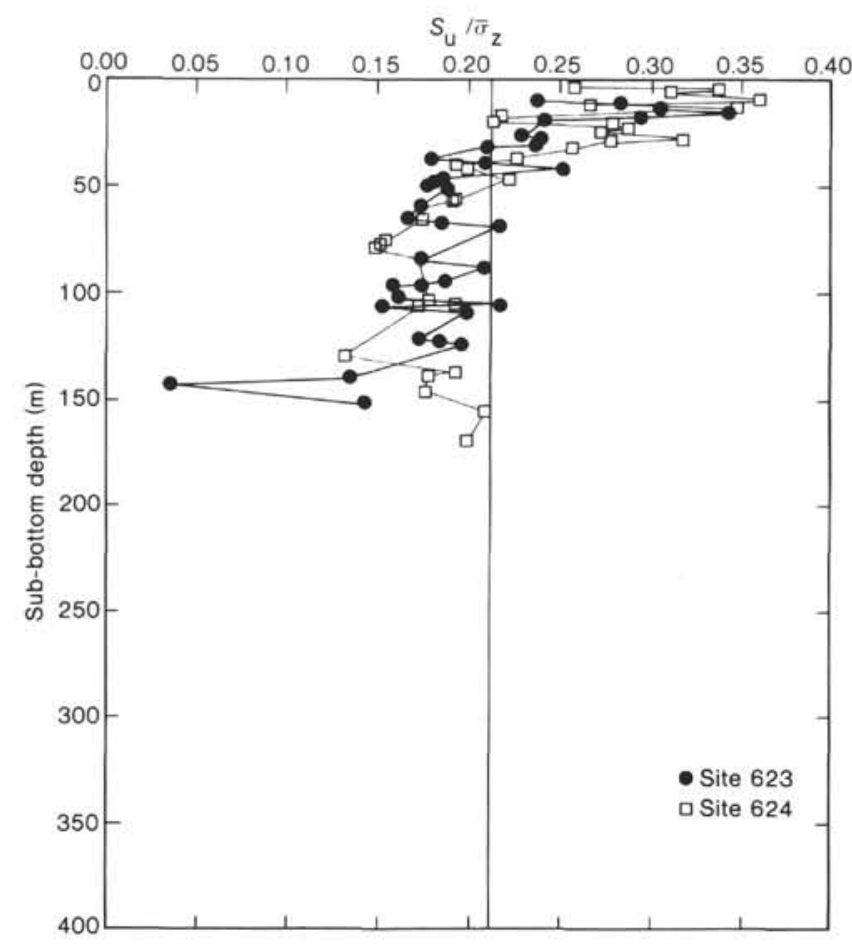

Figure 5. Undrained shear strength-effective overburden stress ratio $\left(S_{\mathrm{u}} / \bar{\sigma}_{\mathrm{z}}\right)$ for Sites 623 and 624 . Sediments with ratios less than 0.22 (to the left of the vertical line) are underconsolidated.

trated near the bottom of Hole 615. Sediments at Site 614 are normally consolidated to a depth of 30 to $40 \mathrm{~m}$, underconsolidated between 40 and $90 \mathrm{~m}$, and normally consolidated at a depth of $100 \mathrm{~m}$; the sediment becomes underconsolidated again at a depth below $110 \mathrm{~m}$ (Fig. 6). At Site 615, the sediments are normally consolidated to a depth of $65 \mathrm{~m}$ and slightly underconsolidated below that depth (Fig. 6).

Examination of the relationship between the shear strength and overburden stress indicates that sediments deposited in the youngest Mississippi Fan lobe are generally underconsolidated below depths of between 25 and $65 \mathrm{~m}$ sub-bottom (Table 1). Although these shear strengthoverburden stress relationships only give indirect indications of the degree of sediment consolidation, they are extremely useful because of the large number of points that can be tested. This means that trends of consolidation characteristics can be generated for a given sediment section; these trends can then be used to determine the sampling and testing scheme for more definitive consolidation investigations (discussed below).

\section{CONSOLIDATION CHARACTERISTICS INFERRED FROM CONSOLIDATION TESTS}

\section{Consolidation Test Methods}

A standard method used to determine the consolidation conditions and amount of excess pore-water pressure that exist in a sediment section is that of measuring the preconsolidation pressure by analysis of void ratio to vertical effective stress relationships by a consolidation test using an oedometer.

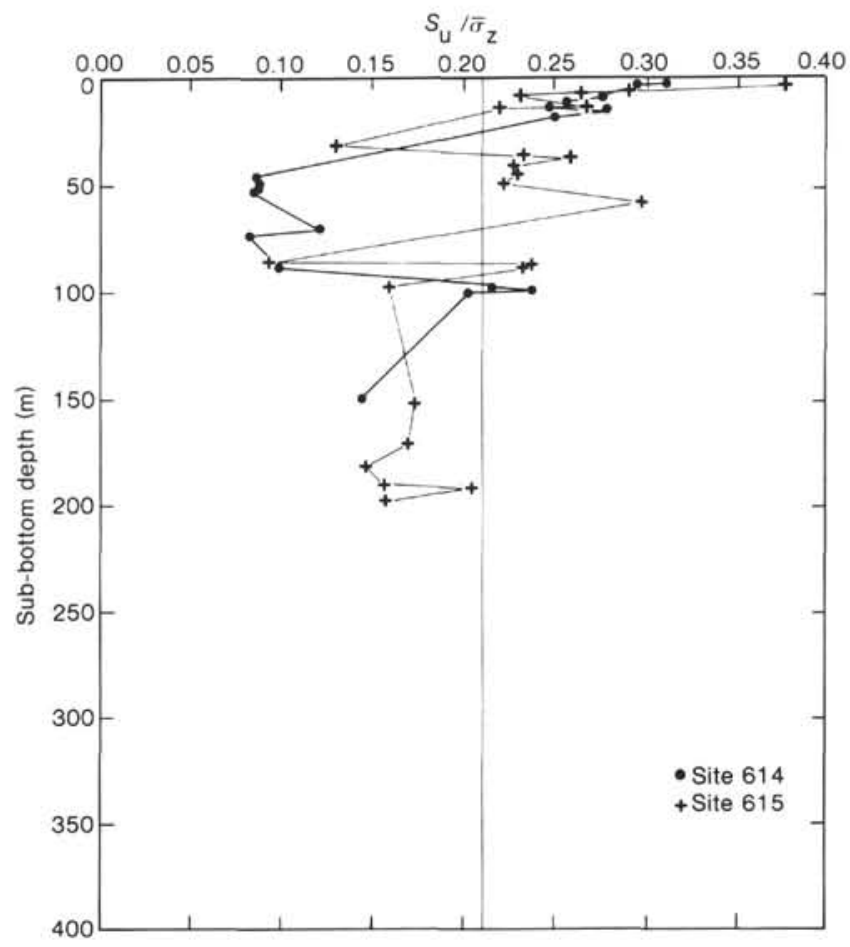

Figure 6. Undrained shear strength-effective overburden stress ratio $\left(S_{\mathrm{u}} / \bar{\sigma}_{\mathrm{z}}\right)$ for Sites 614 and 615 . Sediments with ratios less than 0.22 (to the left of the vertical line) are underconsolidated.

Table 1. Depth to underconsolidated sediments, Mississippi Fan.

\begin{tabular}{cc}
\hline Site & $\begin{array}{c}\text { Sub-bottom depth } \\
(\mathrm{m})\end{array}$ \\
\hline Middle Fan & \\
& \\
617 & 40 \\
620 & 25 \\
621 & $40-50$ \\
622 & $40-50$ \\
616 & 40 \\
& \\
Lower Fan & \\
& \\
614 & $30-40$ \\
615 & 65 \\
623 & 40 \\
624 & 40 \\
\hline
\end{tabular}

One-dimensional consolidation tests were performed on Leg 96 sediments using Anteus back-pressure consolidometers. This involved the incremental loading of a relatively thin, laterally confined sediment sample. Axial strain-time relationships were obtained by measuring the change in sample height during the test. A complete description of this technique can be found in Lambe and Whitman (1969). A variation of this method involves the application of sufficient back pressure to redissolve gas bubbles and completely saturate the consolidation sample. Lowe (1974) discusses the benefits of this method. A serious drawback to both of the above methods is that more than 15 days are required to complete a single 
test, severely limiting the number of samples that can be run in a reasonable time.

Skempton (1970) defined consolidation as the result of all processes that cause the progressive transformation of an argillaceous sediment from a soft clay to a shale. These processes include: (1) interparticle bonding, (2) dessication, (3) cementation, and (4) the squeezing out of pore water under the increasing weight of overburden. The effect of each process on consolidation will vary through time. Because of the relatively young age of the Mississippi Fan sediments, their consolidation state is principally a function of pore-water loss as a result of the weight of the overburden.

Consolidation tests are used to evaluate the sediment response to an applied load. These results provide insight into the relative degree of consolidation the sediment has experienced in situ under the imposed load of the overlying sedimentary column. The state of consolidation is determined using the ratio of preconsolidation stress $\left(\bar{\sigma}_{\mathrm{c}}\right)$ to the calculated present effective overburden stress $\left(\bar{\sigma}_{\mathrm{o}}\right)$. Preconsolidation stress, defined as the maximum effective stress the sediment has experienced, is usually calculated using the graphical reconstruction technique of Casagrande (1936). Various investigators, including Cooling and Skempton (1942), Bishop et al. (1965), Schmertmann (1955), and the Marine Geotechnical Consortium (1985), have concluded that the Casagrande method is inadequate under certain circumstances to define the preconsolidation stress when applied to curves from oedometer (consolidation) tests. Recent results of a study conducted at Texas A\&M University to determine preconsolidation pressures of marine sediments indicate that the Casagrande method underestimates preconsolidation pressures by $35 \%$ or more. Other procedures for the determination of preconsolidation pressures, based on the rebound characteristics of the sediments, have been proposed by Burmister (1951) and Schmertmann (1955). Alternate methods based on the rebound characteristics and modification of the Casagrande method have been developed at Texas A\&M University. A brief discussion of these alternate methods follows.

Examination of numerous compression curves showed that as the magnitude of the expansion index increases, the error in the determination of the preconsolidation stress, as determined by the Casagrande method, also increases. Analysis of compression curves containing a hysteresis loop has been used to develop a relationship between the expansion index and the preconsolidation pressure as determined by the Casagrande method. This relationship was used to adjust the values of the preconsolidation pressure determined from the initial reload portion of the compression curve using the Casagrande method. The adjusted values are assigned the term $\sigma_{\mathrm{c} 5}$ in Figure 7.

Another method to determine the preconsolidation pressure is based on the rebound curve characteristics and the assumption that the rebound characteristics are constant for a given sediment sample. Examination of all the compression curves in this study with rebound portions substantiates this assumption. Schmertmann (1955) addressed a similar problem and demonstrated

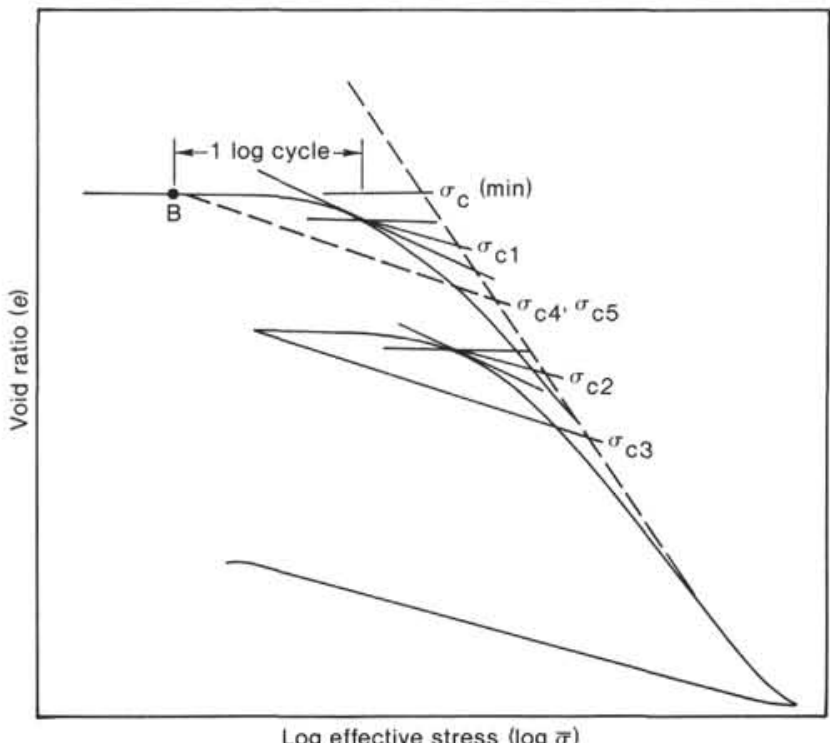

Figure 7. Hypothetical void ratio-log effective stress ( $e$ versus $\log \bar{\sigma})$ curve showing how the calculated preconsolidation stress varies depending on the technique used (see explanation in text). $\sigma_{\mathrm{c}}(\mathrm{min})$ is the minimum value of preconsolidation stress. $\sigma_{\mathrm{c} 1}$ is the preconsolidation stress calculated using the Casagrande (1936) technique. $\sigma_{\mathrm{c} 2}$ is the preconsolidation stress calculated using the maximum point of curvature on the reloading part of the $e$ versus $\log \bar{\sigma}$ curve. This is significantly lower than the actual preconsolidation stress at the start of unloading, $\sigma_{\mathrm{c} 3} . \sigma_{\mathrm{c} 4}$ is the preconsolidation pressure determined from rebound characteristics and the point of maximum void ratio (point $\mathrm{B}), \sigma_{\mathrm{cs}}$ is the preconsolidation pressure determined from $\sigma_{\mathrm{c} 5}=\sigma_{\mathrm{c} 1} \times \sigma_{\mathrm{c} 3} / \sigma_{\mathrm{c} 2}$. See text for further information.

that variations are predictable. The rebound method to determine the preconsolidation pressure is as follows: a point on the constant (maximum) void ratio line during the first laboratory loading is chosen. This point is the largest vertical effective stress along the line of constant $e$ and corresponds to point $\mathrm{B}$ in Figure 7. If that point appears ambiguous, a point one log cycle before the point of maximum curvature on the reload curve is used. From that point a line parallel to the rebound portion of the compression curve is extended to intersect the virgin curve. That intersection is determined to be the preconsolidation pressure. Values derived by this method are assigned the term $\sigma_{\mathrm{c} 4}$ in Figure 7.

A minimum value of the preconsolidation pressure was determined to be the intersection of the extension of the virgin curve to the horizontal extension of the reload portion of the $e$ versus $\log \bar{\sigma}$ curve. Values derived by this method are assigned the term $\sigma_{\mathrm{c}}(\mathrm{min})$ in Figure 7.

The values of preconsolidation pressures used in this chapter are the minimum values as determined by the methods described directly above and the maximum values determined by either the Casagrande method $\left(\sigma_{\mathrm{cl}}\right)$, the modified Casagrande method $\left(\sigma_{\mathrm{c} 5}\right)$, or the rebound method $\left(\sigma_{\mathrm{c} 4}\right)$.

The ratio of the preconsolidation stress to the calculated effective overburden stress yields the overconsolidation ratio (OCR $=\bar{\sigma}_{\mathrm{c}} / \bar{\sigma}_{\mathrm{o}}$ ). Thus, for a normally consolidated sediment where the preconsolidation stress equals or closely approximates the effective overburden 
stress $\left(\bar{\sigma}_{\mathrm{c}}=\bar{\sigma}_{\mathrm{o}}\right)$, the OCR value is 1 . A sediment is considered overconsolidated if it has been consolidated under a stress that exceeds the present effective overburden stress $\left(\bar{\sigma}_{\mathrm{c}}>\bar{\sigma}_{\mathrm{o}}\right)$. Sediment that has not fully consolidated under the present overburden stress is underconsolidated. For underconsolidated sediments, the porewater pressure exceeds the hydrostatic pressure and the preconsolidation stress will be less than the true effective overburden stress $\left(\bar{\sigma}_{\mathrm{c}}<\bar{\sigma}_{\mathrm{o}}\right)$. Essentially, excess pore pressures result in lower effective overburden stress compared to values computed assuming hydrostatic conditions. Thus, sediments with overconsolidation ratios of approximately 1.0 are considered normally consolidated, greater than 1.0 are overconsolidated, and less than 1.0 are underconsolidated.

\section{Results of Consolidation Tests}

Forty consolidation tests were performed on samples from the nine Mississippi Fan sites. Twenty-three of these tests were performed in the Geotechnical Laboratory at Texas A\&M University; the remaining tests were run at the Universität Tübingen, Germany.

The results of consolidation tests are displayed on void ratio-log of vertical effective stress diagrams. An example of these results from samples taken at 1.4, 10, 89, and $307 \mathrm{~m}$ sub-bottom depth from Site 615 is shown in Figure 8. The sample taken at the $1.4-\mathrm{m}$ level had an initial void ratio of approximately 3.00 and a final void ratio of 0.80 at a vertical effective stress (i.e., effective overburden stress) of $3200 \mathrm{kPa}$, and serves as a good example of the large amount of volume reduction (decrease

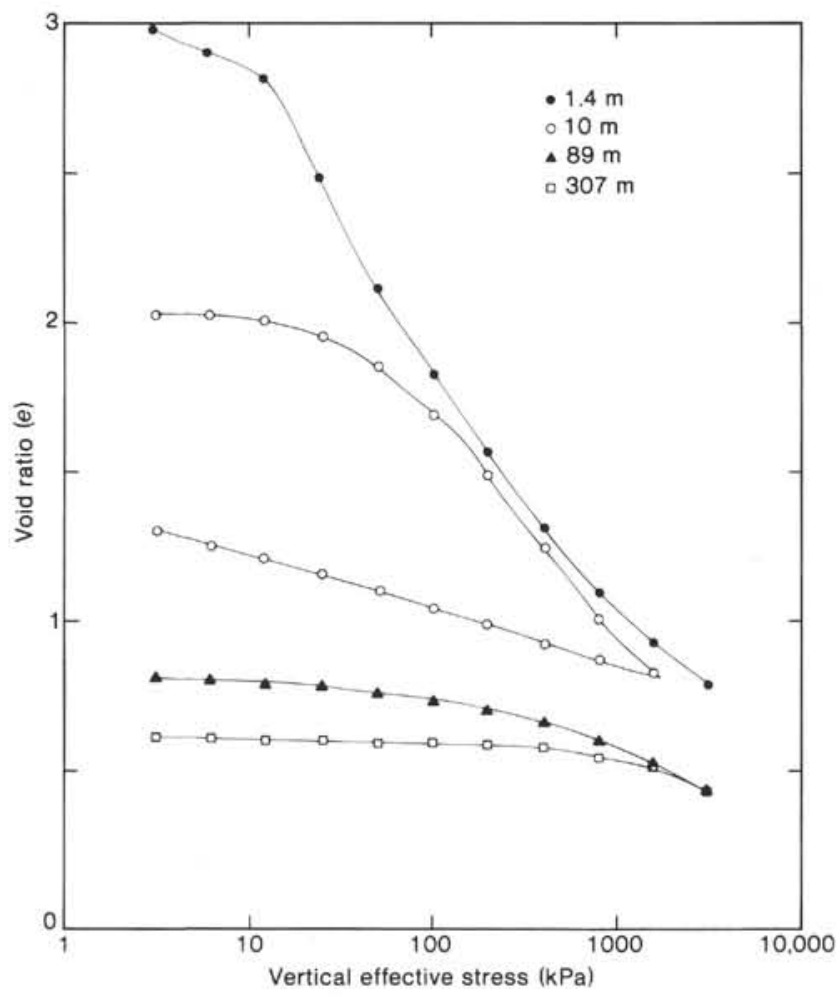

Figure 8. Void ratio-log of vertical effective stress plots of sediments from Site 615 at $1.4,10,89$, and 307 m below the seafloor. in void ratio) that high-water-content sediments undergo with relatively small increases in effective overburden stress. These sediments undergo as much reduction in void ratio under an increase in stress of 2 to $100 \mathrm{kPa}$ as they do under a subsequent increase in stress of 100 to $3200 \mathrm{kPa}$. This may in part explain the conditions expressed by the shear-strength-overburden relationships where the sediments become underconsolidated at a depth of approximately $40 \mathrm{~m}$ sub-bottom, equivalent to a vertical effective stress of $200 \mathrm{kPa}$.

Results from Site 615 also show that if all the sediment samples were subjected to sufficient stress, their final void ratio would be similar (Fig. 8). The rebound portion of the curve for the sample taken at $10 \mathrm{~m}$ subbottom indicates that these sediments are fairly elastic and are subject to an increase in void ratio of up to $40 \%$ with the release of the vertical effective stress.

Table 2 lists the calculated effective overburden stress, preconsolidation stress, overconsolidation ratio (OCR), consolidation characteristics, and excess pore-water pressures for the 40 samples measured from the Mississippi Fan sediments. The values listed for the preconsolidation stress $\left(\bar{\sigma}_{\mathrm{c}}\right)$ cover a range from the absolute minimum to the absolute maximum values that can be obtained by using the four different methods described above for determining the preconsolidation stress.

Figure 9 shows plots of the calculated in situ vertical effective stress (overburden pressure) under hydrostatic conditions as a function of depth at the nine sites drilled on the Mississippi Fan. Also plotted on the figure is the range of the absolute minimum and maximum values of the preconsolidation stress $\left(\bar{\sigma}_{\mathrm{c}}\right)$ as determined from the consolidation tests. The difference between the preconsolidation stress and the vertical effective stress (UHC) is the approximate amount of pressure in excess of hydrostatic that one would expect in the underconsolidated sediments. For example, in Figure $9 \mathrm{C}$ at Sites 617 and 620 , the excess pore-water pressures at the 120 to $124 \mathrm{~m}$ depth level would range from a maximum of $705 \mathrm{kPa}$ to a minimum of $385 \mathrm{kPa}$ in excess of hydrostatic or from 40 to $67 \%$ of the vertical effective stress (UHC). The shaded areas of each figure represent the range of the in situ vertical effective stress in the presence of excess porewater pressures.

During the drilling operations at Site 620 a pressure of approximately $2460 \mathrm{kPa}(350 \mathrm{psi})$ was required to maintain circulation at the $395-\mathrm{m}$ depth level. Even at this pump pressure, the drill string became stuck. Downhole pressures of $2460 \mathrm{kPa}$ at $395 \mathrm{~m}$ below the seafloor translate to an excess pore-water pressure (abnormal pressure) equal to $78 \%$ of vertical effective stress (UHC). The one consolidation test run on Site 620 sediments shows that, at a depth of $119 \mathrm{~m}$, the sediments are in a state of high underconsolidation (Table 2). The value of the overconsolidation ratio (OCR) ranged from 0.33 to 0.59 . An OCR value of 0.33 means that the downhole excess porewater pressures are $67 \%$ of the total vertical effective stress (UHC). Projecting the underconsolidation trend with depth, it is then possible to account for excess porewater pressures equal to $78 \%$ of the vertical effective stress at the $395 \mathrm{~m}$ sub-bottom level. 
Table 2. Consolidation characteristics and excess pore-water pressures for Mississippi Fan sediments.

\begin{tabular}{|c|c|c|c|c|c|c|c|}
\hline Site & $\begin{array}{l}\text { Sub-bottom } \\
\text { depth } \\
\text { (m) }\end{array}$ & $\begin{array}{l}\text { Effective } \\
\text { overburden } \\
\text { stress, } \bar{\sigma}_{\mathrm{O}} \\
(\mathrm{kPa})\end{array}$ & $\begin{array}{l}\text { Minimum and } \\
\text { maximum } \\
\text { preconsolidation } \\
\text { stress, } \bar{\sigma}_{\mathrm{c}} \\
(\mathrm{kPa})\end{array}$ & $\begin{array}{l}\mathrm{OCR}^{\mathrm{a}} \text { for } \\
\text { average and } \\
\text { high values } \\
\text { of } \bar{\sigma}_{\mathrm{C}}\end{array}$ & $\begin{array}{c}\text { Consolidation } \\
\text { characteristics } \\
\text { (average-high } \\
\bar{\sigma}_{\mathrm{c}} \text { ) }\end{array}$ & $\begin{array}{c}\text { Minimum } \\
\text { pore-water } \\
\text { pressure } \\
(\mathrm{kPa})\end{array}$ & $\begin{array}{c}\text { Maximum } \\
\text { pore-water } \\
\text { pressure } \\
(\mathrm{kPa})\end{array}$ \\
\hline \multicolumn{8}{|c|}{ Lower Fan } \\
\hline \multirow[t]{2}{*}{614} & 7 & 35 & $40-46$ & $1.23-1.31$ & $\mathrm{OC}$ & 0 & 0 \\
\hline & 100 & 805 & 800 & $0.99-0.99$ & NC & 0 & 0 \\
\hline \multirow[t]{8}{*}{615} & 1.4 & 15 & 16 & $1.06-1.06$ & NC & 0 & 0 \\
\hline & 10 & 45 & $30-60$ & $1.00-1.30$ & $\mathrm{NC}-\mathrm{OC}$ & 0 & 15 \\
\hline & 19.5 & 107 & 180 & $1.34-1.68$ & OC & 0 & 0 \\
\hline & 37.1 & 256 & $120-400$ & $1.01-1.56$ & NC-OC & 0 & 0 \\
\hline & 46.5 & 339 & $40-60$ & $0.17-0.14$ & HUC & 279 & 299 \\
\hline & 89 & 711 & $100-410$ & $0.35-0.57$ & HUC & 301 & 511 \\
\hline & 198.2 & 1842 & $600-1400$ & $0.54-0.76$ & HUC-UC & 442 & 1242 \\
\hline & 307 & 2664 & 200 & 0.07 & HUC & 2464 & 2464 \\
\hline \multirow[t]{2}{*}{623} & 5.9 & 30 & 33 & 1.13 & NC & 0 & 0 \\
\hline & 95.9 & 671 & $200-530$ & $0.54-0.78$ & HUC-UC & 141 & 471 \\
\hline \multirow[t]{6}{*}{624} & 12.8 & 70 & $20-43$ & $0.45-0.61$ & HUC-UC & 27 & 50 \\
\hline & 27.5 & 146 & $13-50$ & $0.21-0.34$ & HUC & 96 & 133 \\
\hline & 38.7 & 217 & $125-130$ & $0.58-0.59$ & HUC & 87 & 92 \\
\hline & 56.3 & 366 & $130-230$ & $0.49-0.62$ & HUC & 136 & 236 \\
\hline & 104.2 & 1136 & $400-1370$ & $0.77-1.20$ & HUC-OC & 0 & 736 \\
\hline & 137.8 & 970 & $200-500$ & $0.36-0.51$ & HUC & 470 & 770 \\
\hline \multicolumn{8}{|c|}{ Middle Fan } \\
\hline \multirow[t]{9}{*}{616} & 4.4 & 20 & 20 & 1.00 & $\mathrm{NC}$ & 0 & 0 \\
\hline & 10.9 & 112 & $46-140$ & $0.83-1.25$ & $\mathrm{NC}-\mathrm{OC}$ & 0 & 60 \\
\hline & 51.7 & 313 & $130-420$ & $0.87-1.34$ & NC-OC & 0 & 183 \\
\hline & 75.9 & 532 & $100-400$ & $0.46-0.75$ & HUC-UC & 132 & 432 \\
\hline & 96.7 & 645 & $340-900$ & $0.96-1.39$ & NC-OC & 0 & 305 \\
\hline & 105 & 783 & $500-700$ & $0.76-0.89$ & UC & 83 & 653 \\
\hline & 142.5 & 1024 & $375-1100$ & $0.72-1.07$ & UC-NC & 0 & 649 \\
\hline & 307.2 & 2628 & $600-800$ & $0.26-0.30$ & HUC & 1828 & 2028 \\
\hline & 331.4 & 2878 & $500-1600$ & $0.31-0.56$ & HUC & 1278 & 2378 \\
\hline \multirow[t]{8}{*}{617} & 5.9 & 30 & 30 & 1.00 & $\mathrm{NC}$ & 0 & 0 \\
\hline & 10.9 & 62 & $30-50$ & $0.64-0.80$ & UC & 10 & 32 \\
\hline & 23.6 & 121 & $70-100$ & $0.70-0.83$ & UC & 21 & 51 \\
\hline & 42.8 & 275 & $170-235$ & $0.73-0.85$ & UC & 40 & 105 \\
\hline & 61.7 & 445 & $200-410$ & $0.68-0.92$ & UC-NC & 35 & 245 \\
\hline & 100.1 & 770 & $440-1000$ & $0.93-1.29$ & $\mathrm{NC}-\mathrm{OC}$ & 0 & 330 \\
\hline & 124 & 945 & $240-560$ & $0.40-0.59$ & HUC & 385 & 705 \\
\hline & 152.8 & 1229 & $340-1050$ & $0.56-0.85$ & HUC-UC & 179 & 620 \\
\hline 620 & 119.9 & 751 & $250-450$ & $0.33-0.59$ & HUC & 301 & 501 \\
\hline \multirow{2}{*}{621} & 35.2 & 444 & $130-460$ & $0.66-1.06$ & NC & 0 & 314 \\
\hline & 138.8 & 1100 & $400-600$ & $0.45-0.54$ & HUC & 500 & 700 \\
\hline \multirow{2}{*}{622} & 4.9 & 26 & $22-40$ & $1.19-1.53$ & $\mathrm{OC}$ & 0 & 4 \\
\hline & 73 & 531 & $240-600$ & $0.79-1.12$ & NC & 0 & 291 \\
\hline
\end{tabular}

${ }^{\mathrm{a}} \mathrm{OCR}=$ overconsolidation ratio

$\mathrm{b}$ NC $=$ normally consolidated, $\mathrm{UC}=$ underconsolidated, $\mathrm{HUC}=$ highly underconsolidated, and $\mathrm{OC}=$ overconsolidated.

A minimum OCR value of 0.07 was measured for sediments from $307 \mathrm{~m}$ sub-bottom at Site 615 (Table 2). This high degree of underconsolidation suggests that downhole conditions at Site 615 are such that the excess pore-water pressures almost equal the vertical effective stress. This conclusion, however, is based on only one sample, which may have been highly disturbed.

In general, the middle fan sediments show a higher degree of underconsolidation than lower fan sediments. This trend probably results from the relatively lower rates of accumulation for the lower fan sediments as well as the more rapid draining of the pore water in the sediments through the higher permeability sands that are more common to the lower fan.

As an aid in the correlation of other sediment properties with consolidation characteristics, a summary of other related geotechnical properties-both the seafloor values and downhole vertical gradients-are listed in Table 3.

\section{PERMEABILITY AND COEFFICIENT OF CONSOLIDATION}

\section{Permeability Test Methods}

The movement or flux of interstitial pore water within marine deposits caused by the effects of consolidation is controlled by the permeability of the sediments which, in turn, is a function of grain size, sorting, and porosity. Permeability is a major variable influencing the consolidation process, the resultant pore-water flux, and the diffusion of ionic species.

As defined by Gray et al. (1972), permeability is "the property or capacity of a porous rock, sediment, or soil for transmitting a fluid without impairment of the structure of the medium." There are several methods of determining permeability both in the field and in the laboratory. Permeabilities may be computed by the use of a laboratory consolidation test on the basis of the equation developed by Terzaghi (1943). This test permits the 

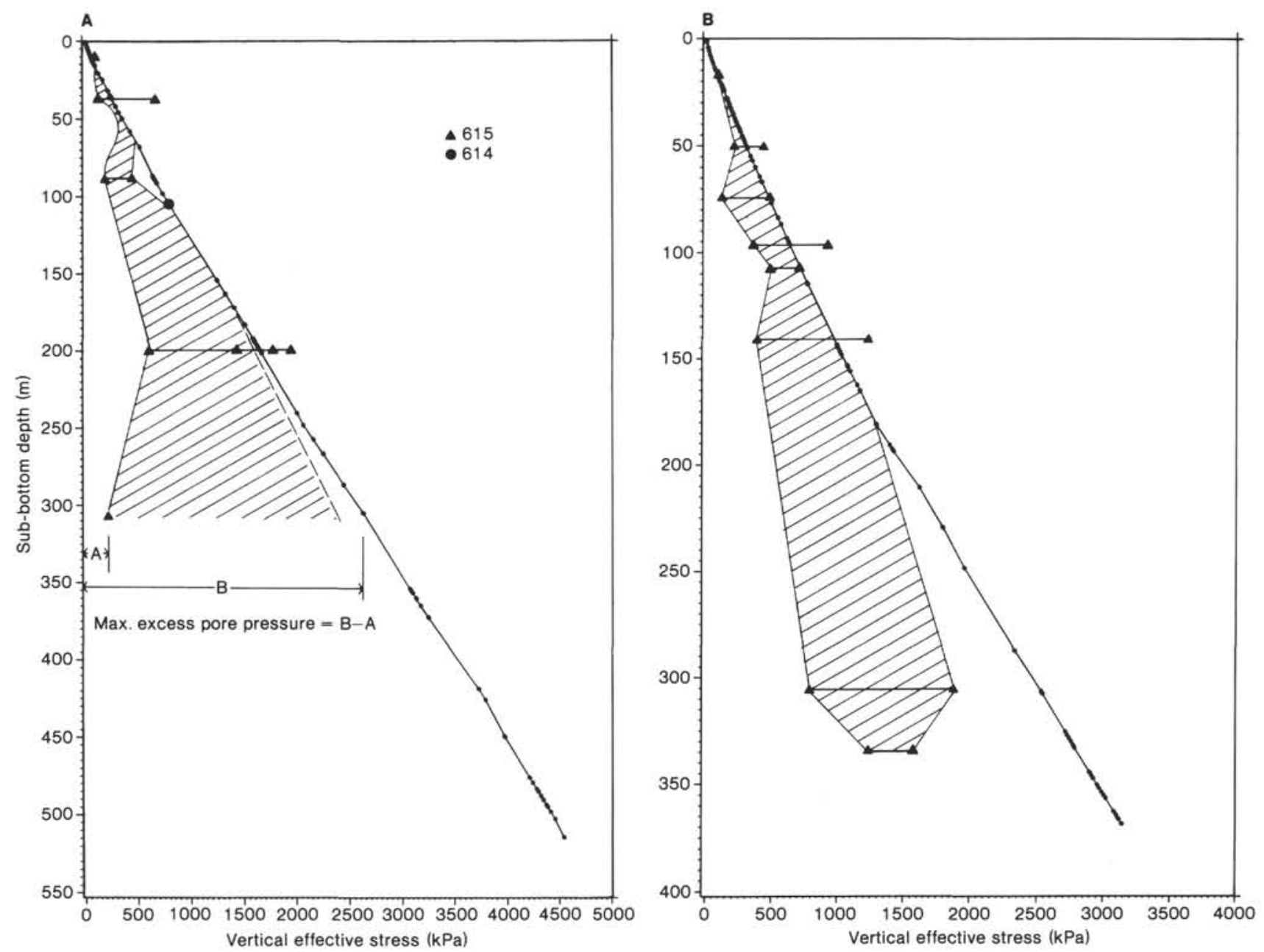

Figure 9. Plot of vertical effective stress (overburden pressure) assuming hydrostatic conditions as a function of sub-bottom depth at (A) Sites 615 and 614, (B) Site 616, (C) Sites 617 and 620, (D) Sites 621 and 622, (E) Site 623, and (F) Site 624. The shaded area shows the range of the minimum and maximum excess pore-water pressures. The left-hand boundary of the shaded area is the maximum excess pore-water pressure found at any particular level. The circles and triangles represent the minimum and maximum values of the preconsolidation stress as determined from the consolidation tests at the sites. The vertical effective stress in the presence of excess pore-water pressures would fall somewhere in the shaded area.

assessment of the compressibility of a soil sample under a given load resulting from the escape of pore water which, in turn, is inversely related to the coefficient of permeability $(k)$ of a sample under a particular pressure or stress. All permeability data presented herein were routinely computed from laboratory consolidation tests on either 6.35 - or 4.45 -cm-diameter samples having initial heights of about $2.54 \mathrm{~cm}$.

The laboratory determination of permeability usually consists of the use of either a falling or variable-head permeameter, a constant-head permeameter, or by indirect measurement from the results of a consolidation (oedometer test) (Lambe, 1951). The square root of the time-fitting method was employed to determine the time required for $90 \%$ primary consolidation $\left(t_{90}\right)$. To determine $t_{90}$, the compression dial reading was plotted against the square root of elapsed time. Tangents were drawn from the straight-line portion of the observed curve back to the zero time intersect. Through the intersect of zero time a straight line was drawn having an inverse slope equal to 1.15 times the tangent. The intersection of this line with the time-compression dial curve represents the time required to reach $90 \%$ primary consolidation.

The calculation of permeability was based on Terzaghi's (1943) equation for the theory of consolidation:

$$
c_{\mathrm{v}}=\frac{k(1+e)}{\gamma_{\mathrm{w}} a_{\mathrm{v}}}=\frac{k}{\gamma_{\mathrm{w}} m_{\mathrm{v}}}
$$

or

$$
k=c_{\mathrm{v}} m_{\mathrm{v}} \gamma_{\mathrm{w}}
$$

where

$$
\begin{aligned}
k= & \text { coefficient of permeability }(\mathrm{cm} / \mathrm{s}), \\
c_{\mathrm{v}}= & \text { coefficient of consolidation }\left(=0.848 H^{2} / t_{90}\right), \\
m_{\mathrm{v}}= & \text { coefficient of volume change }[=(d e / d p) 1 / \\
& \left.(1+e)=a_{\mathrm{v}} /(1+e)\right] \\
a_{\mathrm{v}}= & \text { coefficient of compressibility }(=\mathrm{de} / \mathrm{dp}), \\
e= & \text { void ratio (volume of voids/volume of solids), }
\end{aligned}
$$



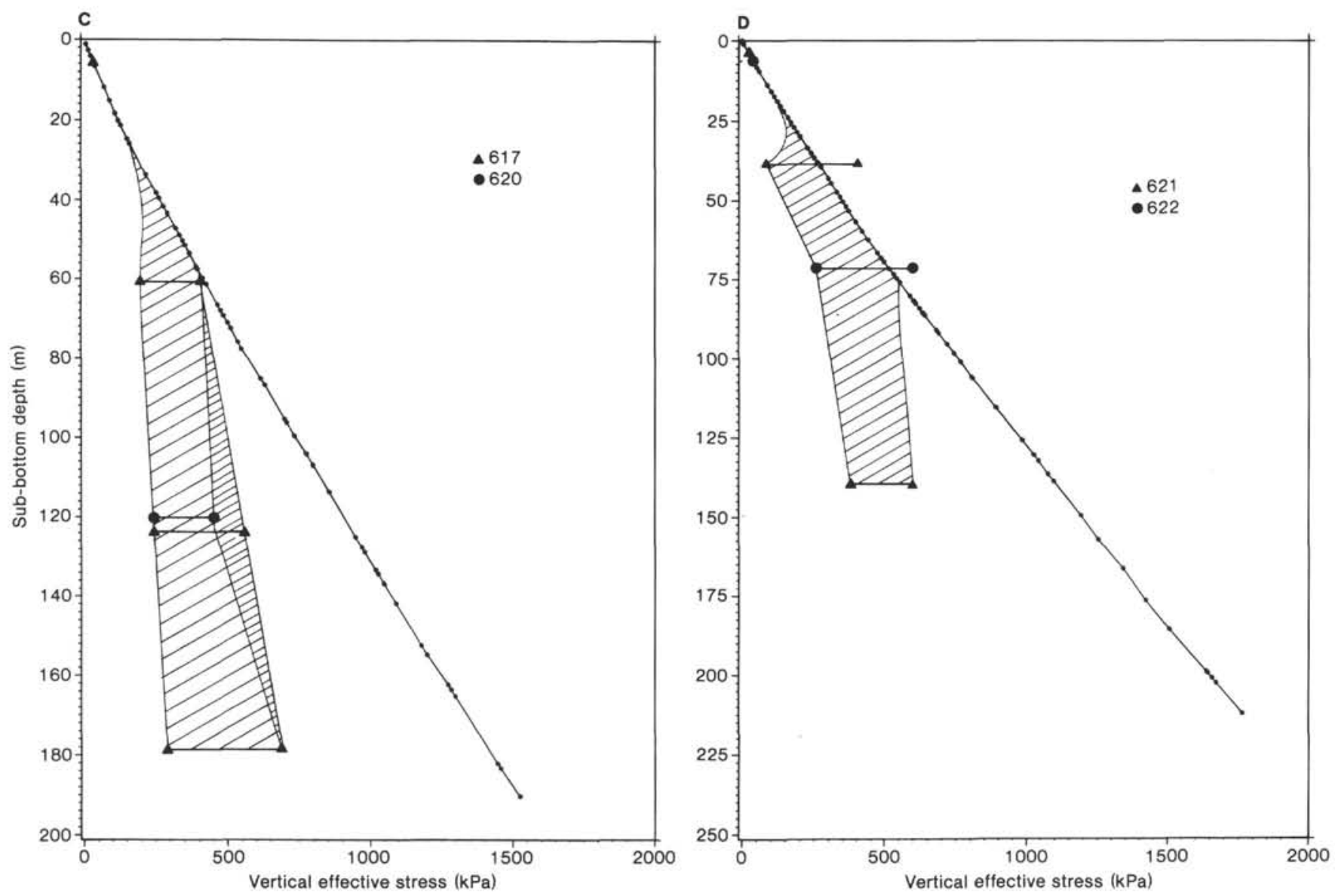

Figure 9 (continued).

$p=$ load pressure, or stress $(\mathrm{kPa})$,

$H=$ average drainage height of the sample $(\mathrm{cm})$,

$t_{90}=$ time required for $90 \%$ completion of primary consolidation, and

$\gamma_{\mathrm{w}}=$ unit weight of pore water (assumed to equal $1.05 \mathrm{~g} / \mathrm{cm}^{3}$ ).

It is interesting to note that the results of calculated permeabilities from consolidation tests are usually one half to one order of magnitude less than from direct measurements using the free-falling head technique (Geotechnical Consortium, 1985).

The single most important characteristic of a sediment relative to permeability is its grain size. To facilitate obtaining meaningful correlations between porosity and permeability, only sediments consisting of predominantly clay-sized material were tested.

\section{Results of Permeability Tests}

Table 4 displays the permeability (coefficient of permeability, $k$ ) of the sediment cored on the Mississippi Fan. This permeability is that observed at the vertical effective stress (UHC) $\left(\bar{\sigma}_{\mathrm{o}}\right)$ level and represents a value that is assumed to approximate the in situ permeability at the level in the core from where the sample was recovered.

There are few geological processes that have such a profound interaction as does the relationship between porosity and permeability of marine clays. Figure 10 dis- plays permeability as a function of porosity of selected samples from Mississippi Fan Sites 614, 616, 621, 622, and 623; results from Site 619 drilled in Pigmy Basin are included for comparison only. The striking feature of permeability is its rapid decrease with decreasing porosity or void ratio. Permeability varies from the fifth to the twelfth power of porosity (Table 5).

The change in permeability relative to depth below the seafloor is illustrated in Figure 11. The values of permeability used in Figure 11 were derived from tests of samples collected from Site 622 taken at the $4.9-\mathrm{m}$ level in the cores. At Site 622, permeability rapidly decreases almost three orders of magnitude within the upper $100 \mathrm{~m}$. By a depth of $500 \mathrm{~m}$, the permeability has decreased to a value that approaches the nano-Darcy range $\left(2 \times 10^{-5} \mathrm{md}, 2 \times 10^{-11} \mathrm{~cm} / \mathrm{s}\right)$. Clays with such low permeabilities could be considered "seals," particularly with regard to hydrocarbon migration. These low permeabilities result in the observed state of high underconsolidation and high excess pore-water pressures such as were predicted at the outset of this study.

\section{Coefficient of Consolidation}

Values of the coefficient of consolidation as determined from consolidation tests are listed in Table 4. The coefficient of consolidation $\left(c_{\mathrm{v}}\right)$ is a measure that defines the rate at which a sediment mass consolidates. It is related to the permeability $(k)$, density of water $\left(\gamma_{\mathrm{w}}\right)$, 


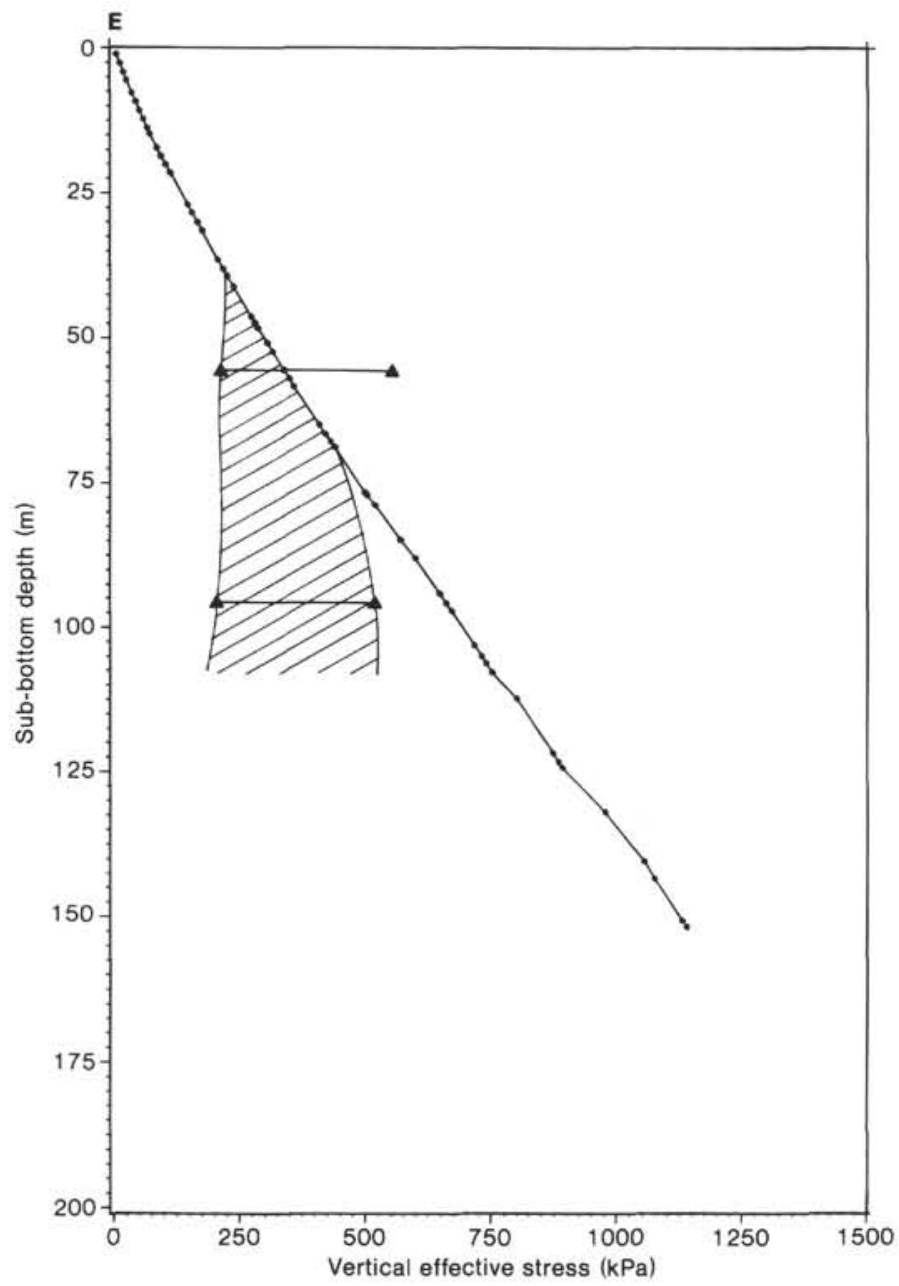

Figure 9 (continued).

and volume compressibility $\left(m_{\mathrm{v}}\right)$ in the following manner:

$$
c_{\mathrm{v}}=\frac{k}{\gamma_{\mathrm{w}} m_{\mathrm{v}}}
$$

Using relationships generated by Gibson (1958), one can estimate the amount of time required for a given sediment section to consolidate to an equilibrium state. The relationship devised by Gibson (1958) for determining the time to reach various degrees of consolidation is as follows:

$$
t=\frac{h^{2}}{T_{1} c_{\mathrm{v}}}
$$

where $t=$ time, $h=$ sediment thickness, and $T_{1}=$ a dimensionless time parameter.

Figure 12 shows the estimated amount of time, assuming constant rates of sedimentation, required for a sediment section of varying thickness to reach $90 \%$ consolidation. The two curves represent consolidation times as a function of two different coefficients of consolidation. The two values of $c_{\mathrm{v}}$ used are typical of the Mississippi Fan sediments and vary by an order of magnitude.

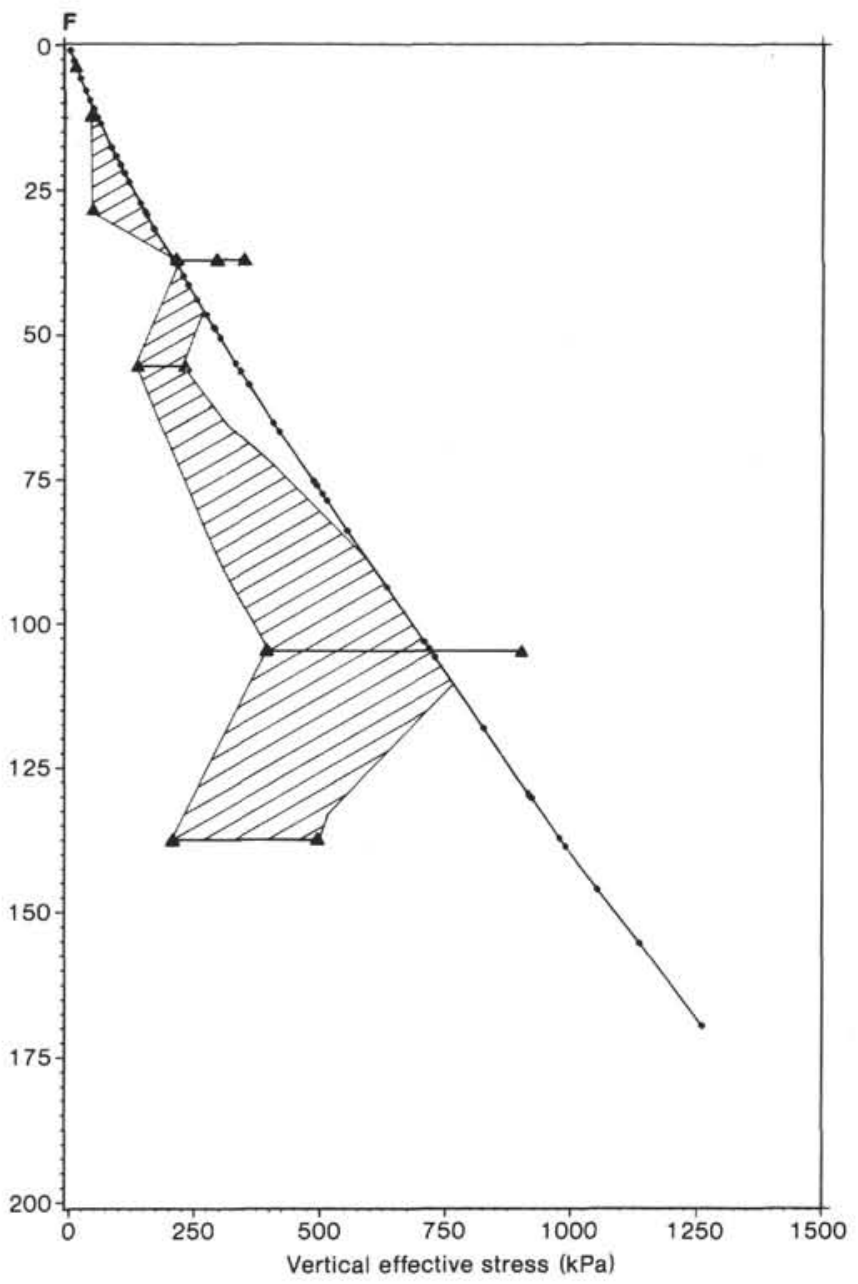

It is obvious that the process of consolidation can be a very slow event. A 1000-m section of Mississippi Fan clay can take from 2.6 to 26 m.y. to consolidate; a $2500-\mathrm{m}$ section could take from 18 to 180 m.y. If sand is present, the time required for consolidation is shortened proportionally to the square of the thickness of the interbedded, fine-grained layer.

The extremely low permeabilities and the low values for the coefficients of consolidation of the Mississippi Fan sediments are the prime cause of the overpressuring (excess pore-water pressures) and the high degree of underconsolidation observed. It will be a long time, even in a geological context, before the Mississippi Fan sediments reach equilibrium. If another glacial event occurs within the next 2-4 m.y., similar to the late Pleistocene events, the rapid loading of the fan may exceed its stability and large portions of the structure could fail, resulting in a situation similar to the Mexican Ridges in the Gulf of Mexico (Buffler et al., 1979).

\section{CONCLUSIONS}

The results of the consolidation tests show similar conditions of consolidation for all sites as expressed by the shear strength/overburden relationship. In general, the upper sediments (40-65 m) are normally consolidated 
Table 3. Seafloor geotechnical properties and gradients of Mississippi Fan sediments. ${ }^{\text {a }}$

\begin{tabular}{|c|c|c|c|c|c|c|c|c|}
\hline Site & $\begin{array}{l}\text { Bulk density } \\
\text { (seafloor) } \\
\left(\mathrm{g} / \mathrm{cm}^{3}\right)\end{array}$ & $\begin{array}{l}\text { Bulk density } \\
\text { gradient } \\
\left(\mathrm{g} / \mathrm{cm}^{3} \text { per } \mathrm{m}\right)\end{array}$ & $\begin{array}{l}\text { Dry water } \\
\text { content } \\
\text { (seafloor) } \\
(\%)\end{array}$ & $\begin{array}{c}\text { Dry water } \\
\text { content } \\
\text { gradient } \\
(\% \text { per } \mathrm{m})\end{array}$ & $\begin{array}{c}\text { Shear } \\
\text { strength } \\
\text { (seafloor) } \\
(\mathrm{kPa})\end{array}$ & $\begin{array}{c}\text { Shear- } \\
\text { strength } \\
\text { gradient } \\
(\mathrm{kPa} \text { per } \mathrm{m})\end{array}$ & $\begin{array}{c}\text { Porosity } \\
(\%)\end{array}$ & $\begin{array}{c}\text { Porosity } \\
\text { gradient } \\
\text { (\% per m) }\end{array}$ \\
\hline \multicolumn{9}{|c|}{ Lower Fan } \\
\hline 614 & 1.55 & 0.009 & 90 & $\begin{array}{c}-1.75 \\
(0-40 \mathrm{~m}) \\
+0.076 \\
(40-130 \mathrm{~m})\end{array}$ & 6 & 0.96 & 72 & $\begin{array}{c}-0.75 \\
(0-40 \mathrm{~m}) \\
+0.076 \\
(40-130 \mathrm{~m})\end{array}$ \\
\hline 615 & 1.47 & $\begin{array}{c}0.011 \\
(0-40 \mathrm{~m}) \\
0.0002 \\
(40-450 \mathrm{~m})\end{array}$ & 105 & $\begin{array}{c}-1.3 \\
(0-50 \mathrm{~m}) \\
-0.02 \\
(40-450 \mathrm{~m})\end{array}$ & 5 & 1.37 & 75 & -0.05 \\
\hline 623 & 1.45 & 0.0036 & 106 & $\begin{array}{c}-2.04 \\
(0-25 \mathrm{~m}) \\
-0.24 \\
(25-150 \mathrm{~m})\end{array}$ & 7.5 & 1.47 & 75 & -0.24 \\
\hline 624 & 1.42 & $\begin{array}{c}0.008 \\
(0-50 \mathrm{~m}) \\
0.0015 \\
(50-150 \mathrm{~m})\end{array}$ & 116 & $\begin{array}{c}-1.64 \\
(0-25 \mathrm{~m}) \\
0.275 \\
(25-170 \mathrm{~m})\end{array}$ & 3 & - & 74 & $\begin{array}{c}-0.40 \\
(0-50 \mathrm{~m}) \\
0.07 \\
(50-150 \mathrm{~m})\end{array}$ \\
\hline \multicolumn{9}{|c|}{ Middle Fan } \\
\hline 161 & 1.45 & $\begin{array}{c}0.006 \\
(0-60 \mathrm{~m}) \\
0.001 \\
(60-368 \mathrm{~m})\end{array}$ & 100 & $\begin{array}{c}-0.90 \\
(0-60 \mathrm{~m}) \\
-0.051 \\
(60-368 \mathrm{~m})\end{array}$ & 6 & $\begin{array}{c}1.07 \\
(0-60 \mathrm{~m}) \\
1.1 \\
(60-368 \mathrm{~m})\end{array}$ & 72 & $\begin{array}{c}-0.18 \\
(0-60 \mathrm{~m}) \\
0.0617 \\
(60-368 \mathrm{~m})\end{array}$ \\
\hline 617 & All samples di & $\begin{array}{c}0.006 \\
(0-35 \mathrm{~m}) \\
0.0001 \\
(35-190 \mathrm{~m}) \\
\text { turbed }\end{array}$ & 84 & $\begin{array}{c}-1.0 \\
(0-35 \mathrm{~m}) \\
-0.096 \\
(35-190 \mathrm{~m})\end{array}$ & 7 & $\begin{array}{c}1.34 \\
(0-35 \mathrm{~m}) \\
0.84 \\
(35-190 \mathrm{~m})\end{array}$ & 70 & $\begin{array}{c}-0.42 \\
(0-35 \mathrm{~m}) \\
-0.058 \\
(35-190 \mathrm{~m})\end{array}$ \\
\hline $\begin{array}{l}620 \\
621\end{array}$ & All samples d & turbed & & & & & & \\
\hline 621 & 1.54 & $\begin{array}{c}0.002 \\
(0-70 \mathrm{~m}) \\
0.0007 \\
(70-212 \mathrm{~m})\end{array}$ & 60 & -1.39 & 2 & $\begin{array}{c}1.29 \\
(0-70 \mathrm{~m}) \\
1.15 \\
(70-212 \mathrm{~m})\end{array}$ & 89 & -0.0667 \\
\hline 622 & 1.62 & 0.0019 & 72 & -0.231 & 12 & 1.25 & 67 & -0.130 \\
\hline
\end{tabular}

${ }^{\text {a }}$ Data given in site chapters (this volume). - means not determined.

Table 4. Coefficient of consolidation and permeability of Mississippi Fan sediments.

\begin{tabular}{|c|c|c|c|}
\hline Site & $\begin{array}{l}\text { Sub-bottom } \\
\text { depth } \\
\text { (m) }\end{array}$ & $\begin{array}{l}\text { Coefficient of } \\
\text { consolidation, } c \\
(\mathrm{~cm} / \mathrm{s})\end{array}$ & $\begin{array}{c}\text { Permeability } \\
(k) \text { (indirect) } \\
\text { (cm/s) }\end{array}$ \\
\hline \multirow[t]{2}{*}{614} & 7 & $5.68 \times 10^{-4}$ & $1.49 \times 10^{-7}$ \\
\hline & 100 & $3.00 \times 10^{-4}$ & $3.37 \times 10^{-9}$ \\
\hline \multirow[t]{3}{*}{615} & & $\begin{array}{l}1.01 \times 10^{-4} \\
1.22 \times 10^{-4}\end{array}$ & $\begin{array}{l}6.03 \times 10^{-8} \\
1.22 \times 10^{-8}\end{array}$ \\
\hline & 89 & $2.20 \times 10^{-4}$ & $8.15 \times 10^{-9}$ \\
\hline & 307 & - & - \\
\hline \multirow[t]{2}{*}{623} & 5.9 & $1.79 \times 10^{-4}$ & $4.19 \times 10^{-9}$ \\
\hline & 95.9 & $2.69 \times 10^{-4}$ & $1.47 \times 10^{-9}$ \\
\hline \multirow[t]{3}{*}{624} & 12.8 & $1.08 \times 10^{-4}$ & $1.01 \times 10^{-8}$ \\
\hline & 56.3 & $4.01 \times 10^{-5}$ & $1.18 \times 10^{-8}$ \\
\hline & 137.8 & $1.40 \times 10^{-4}$ & $7.85 \times 10^{-10}$ \\
\hline \multirow[t]{3}{*}{616} & 4.4 & $3.07 \times 10^{-4}$ & $1.16 \times 10^{-7}$ \\
\hline & 75.9 & $1.02 \times 10^{-4}$ & $2.06 \times 10^{-9}$ \\
\hline & 124 & $9.28 \times 10^{-5}$ & $3.53 \times 10^{-10}$ \\
\hline \multirow[t]{3}{*}{617} & 5.9 & $1.55 \times 10^{-4}$ & $1.52 \times 10^{-8}$ \\
\hline & 61.7 & $1.27 \times 10^{-4}$ & $1.55 \times 10^{-9}$ \\
\hline & 124 & $6.85 \times 10^{-5}$ & $7.00 \times 10^{-10}$ \\
\hline 620 & 119.9 & $2.11 \times 10^{-4}$ & $1.26 \times 10^{-9}$ \\
\hline \multirow[t]{2}{*}{621} & 35.2 & $2.91 \times 10^{-4}$ & $4.75 \times 10^{-9}$ \\
\hline & 138.8 & $1.76 \times 10^{-4}$ & $4.79 \times 10^{-10}$ \\
\hline \multirow[t]{2}{*}{622} & 4.9 & $2.04 \times 10^{-4}$ & $6.89 \times 10^{-8}$ \\
\hline & 73 & $2.92 \times 10^{-4}$ & $6.06 \times 10^{-9}$ \\
\hline
\end{tabular}

Note. - means not determined. and, in some cases, overconsolidated. The sediments below that level are underconsolidated, with the degree of underconsolidation increasing with depth. The significance of these findings are that, at depths below approximately 40 to $65 \mathrm{~m}$, the fan sediments exhibit excess pore-water pressures that sustain the state of underconsolidation. If such conditions continue at depth, and there is no reason to believe otherwise, highly abnormal pressure conditions are expected to exist, which is a condition similar to that found on the northwest continental shelf and upper slopes of the Gulf of Mexico.

Table 3 shows that almost all the gradients of the geotechnical properties change by an order of magnitude at approximately 40 - to $50-\mathrm{m}$ depth in the holes. This change in gradient takes place at the same depth as the transition from normally consolidated to underconsolidated conditions at the various sites. It is not known how these various factors are interrelated.

The major diagenetic process occurring in the Mississippi Fan deposits of the youngest fan lobe is sediment consolidation (compaction). Consolidation results in the expulsion of pore water and reduction of porosity (void ratio). The reduction of porosity results in a decrease in the volume of the sediment mass and a change in the geometry of that mass. Thus, the total geometry of the fan and the geometry of individual sediment sequences are constantly changing with time. If sedimentation was 


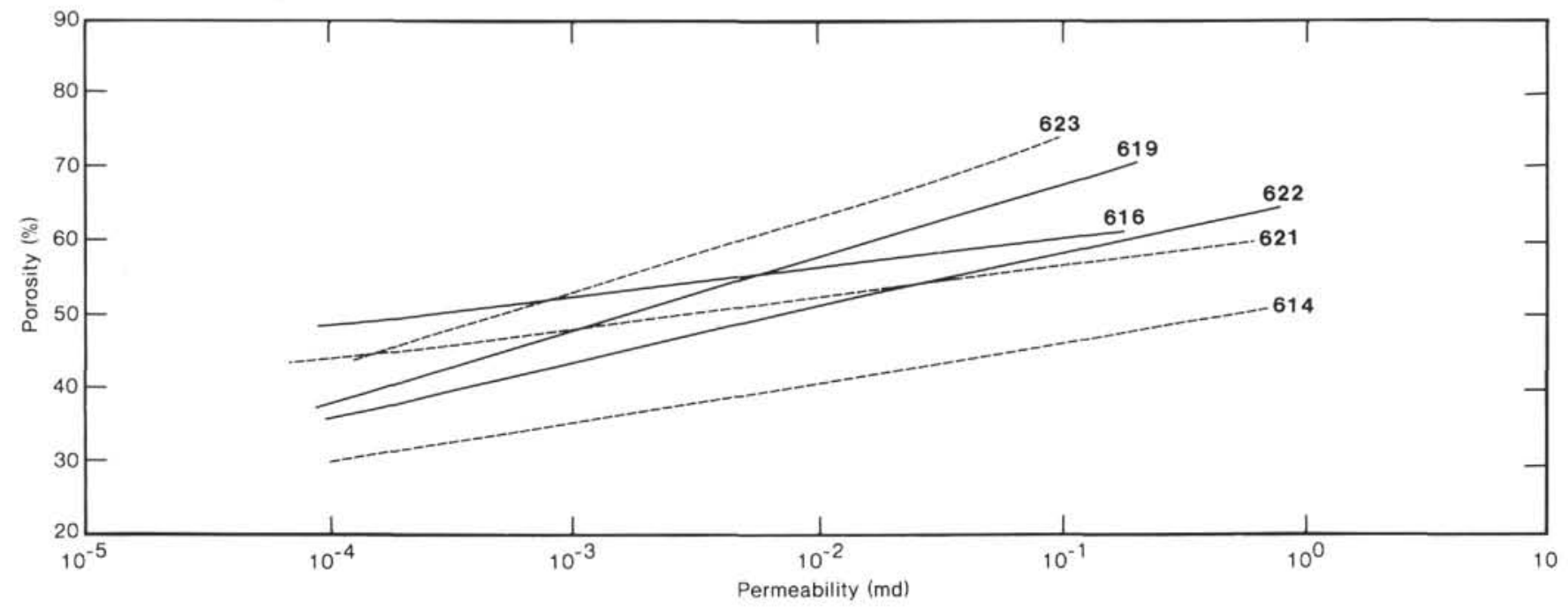

Figure 10. Permeability as a function of porosity of selected samples from Mississippi Fan Sites 614, 616, 621, 622 and 623. The results of testing of samples for Pigmy Basin Site 619 are shown as a comparison.

Table 5. Decrease of permeability relative to power of the porosity.

\begin{tabular}{cc} 
Site & Power of porosity \\
\hline 620 & $10^{5}$ \\
623 & $10^{5}$ \\
622 & $10^{7}$ \\
614 & $10^{9}$ \\
616 & $10^{11}$ \\
621 & $10^{12}$ \\
\hline
\end{tabular}

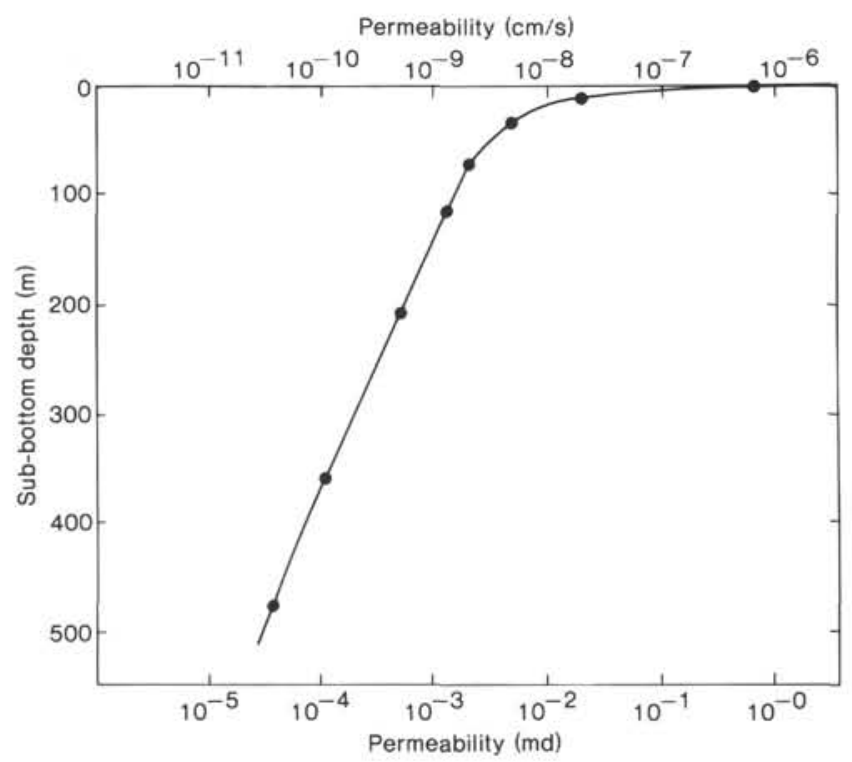

Figure 11. Permeability as a function of depth below the seafloor. The values were derived from the results of testing a sample from Site 622.

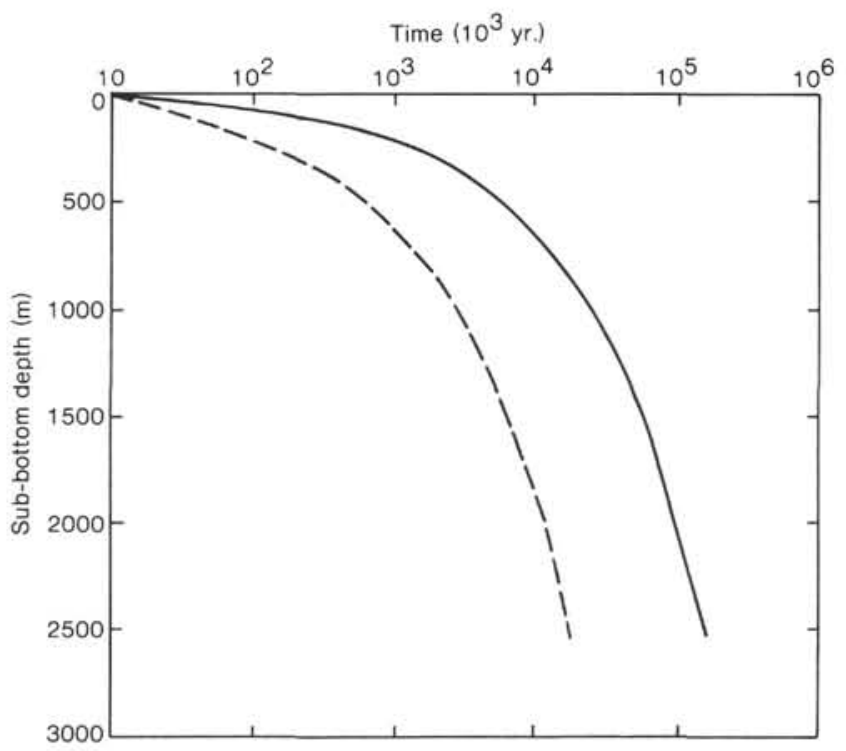

Figure 12. The amount of time required for a clay section of a given thickness to come to a state of normal consolidation. The solid line on the right is determined using a coefficient of consolidation equal to $5 \times 10^{-5} \mathrm{~cm}^{2} / \mathrm{s}$ and the dashed line on the left for a value of $5 \times 10^{-4} \mathrm{~cm}^{2} / \mathrm{s}$.

to cease now, the fan would experience approximately a 15 to $20 \%$ decrease in volume through the subsequent consolidation process.

Consolidation within the Mississippi Fan is a very slow process. Indeed, subsidence resulting from sediment loading of the crust probably proceeds at a faster rate than does the subsidence resulting from the consolidation process. The time required for the Mississippi Fan to achieve a totally normally consolidated state could range from millions to hundreds of millions of years depending upon the rate of accumulation, permeability, coefficient of consolidation, and thickness of sediments. Because the coefficients of consolidation of the sediments on the fan vary widely, the time required to achieve an equilibrium 
state of consolidation also varies greatly. Thus, not only would the amount of reduction in volume of the fan vary with time but the amount of volume reduction would not be equal throughout the various parts of the fan. Unequal volume adjustments would result in a fan with a variable geometry through time.

Geologic reconstructions and fan models should take into consideration the effects of the consolidation process, which are reflected in the porosity of the sediments. Subsidence from crustal loading and subsidence from compaction may prove to be equally important in the interpretation of marine fans.

High rates of accumulation of low-permeability sediments such as are present in the Mississippi Fan result in a sediment mass with a low effective stress. Such a mass is especially susceptible to slope failure and mass movements. Slumping and detachment or décollement similar to that found on the Mexican Ridges in the Gulf of Mexico could well lie in the future geologic history of the Mississippi Fan.

\section{ACKNOWLEDGMENTS}

L. Shephard and H. Lee reviewed an earlier draft of this manuscript.

\section{REFERENCES}

Bishop, A. W., Webb, D. L., and Lewis, P. I., 1965. Undisturbed samples of London Clay from the Ashford Common Shaft: strengtheffective stress relationship. Geotechnique, 15:1-31.

Buffler, R. T., Schaub, F. J., Watkins, J. S., and Worzel, J. L., 1979. Anatomy of the Mexican Ridges, Southwestern Gulf of Mexico. In Watkins, J. S., Montadert, L., and Dickerson, P. W. (Eds.), Geological and Geophysical Investigations of Continental Margins. Am. Assoc. Pet. Geol. Mem., 29:319-327.
Burmister, D. M., 1951. The application of controlled test methods in consolidation testing. Consolidation Testing of Soils, Am. Soc. Testing Materials, 126:83-91.

Casagrande, A., 1936. The determination of the preconsolidation load and its practical significance. Proc. First Int. Conf. Soil Mech. Found. Eng., 3:60-64.

Cooling, L. F., and Skempton, A. W., 1942. A laboratory study of London clay. J. Inst. Civil Eng. London, 17:251-256.

Ericson, D. B., and Wollin, G., 1968. Pleistocene climates and chronology in deep-sea sediments. Science, 162:1227-1234.

Gibson, R. E., 1958. The progress of consolidation in a clay layer increasing in thickness with time. Geotechnique, 8:171-182.

Gray, M. R., McAffe, R., Jr., and Wolf, C. L. (Eds.), 1972. Glossary of Geology: Washington, D. C. (American Geological Institute).

Lambe, T. W., 1951. Soil Testing for Engineers: New York (John Wiley \& Sons).

Lambe, T. W., and Whitman, R. V., 1969. Soil Mechanics: New York (John Wiley \& Sons).

Lowe, J. III, 1974. New concepts in consolidation and settlement analysis. J. Geotech. Eng. Div. Am. Soc. Civil Eng., 100(GT6), 574612.

Marine Geotechnical Consortium, 1985. Geotechnical properties of Northwest Pacific pelagic clays, Deep Sea Drilling Project Leg 86, Hole 576A. In Heath, G. R., Burckle, L. H., et al., Init. Repts. DSDP, 86: Washington (U.S. Govt. Printing Office), 723-758.

Schmertmann, J. H., 1955. The undisturbed consolidation behavior of clay. Trans. Am. Soc. Civil Eng., 120:1201-1227.

Skempton, A. W., 1970. The consolidation of clays by gravitational compaction. Q. J. Geol. Soc. London, 125:373-411.

Terzaghi, K., 1943. Theoretical Soil Mechanics: New York (John Wiley \& Sons).

Walker, J. R., and Massingill, J. V., 1970. Slump features on the Mississippi Fan, Northeastern Gulf of Mexico. Geol. Soc. Am. Bull., 81:3101-3108.

Date of Initial Receipt: 6 February 1985

Date of Acceptance: $\mathbf{2 8}$ July $\mathbf{1 9 8 5}$ 